gradient focusing is not used and the uniform guiding magnetic field is forced beyond the saturation value over a vacuum system of relatively large aperture. Beam stability is obtained by wedge-focusing effects at the boundaries of the sectors into which the 200 -ft. diameter magnet ring is divided. As a result of the fairly large aperture and high injection energy $\left(50 \mathrm{MeV}\right.$.), pulses of about $10^{12}$ protons of an energy of $12.5 \mathrm{GeV}$. are expected. Much of this beam should be available outside the machine.

The Argonne Zero Gradient Synchrotron and its associated equipment will cost 29 million dollars. It will provide a strong source of all known particles and anti-particles and, since it will be especially suited to the study of rare events, it may lead to the discovery of new phenomena. The cost of such research now far exceeds the resources of individual institutions, and the development of great national or international laboratories, in which many university teams conduct research with one accelerator, is a natural consequence. The new undertaking at Argonne, which it is hoped to complete during 1962-63, has many similarities to that at Harwell, where a $7 \mathrm{GeV}$. proton synchrotron is under construction for the National Institute for Research in Nuclear Science.

\section{Higher Education in the U.S.S.R.}

A BIBLIOGRAPHICAL survey of technical and vocational education in the U.S.S.R. by M. I. Movšovič issued as No. 30 of educational studies and documents by the United Nations Educational Scientific and Cultural Organization (Technical and Vocational Education in the U.S.S.R. : a Bibliographical Survey. By M. I. Movšovič. Pp. 53. Paris : Unesco ; London : H.M. Stationery Office, 1959. 5s. net), covers vocational education at the elementary, secondary and higher levels. Besides books and articles, bibliographies and periodicals are dealt with in a separate section. Generally, publications are presented chronologically within each section and the articles are fairly fully annotated or summarized.

\section{Planning in Pakistan}

A BROADsHeEr, "Planning in Pakistan" (Planning, Vol. 25, No. 433, April 20, 1959. Pp. 85-112. London: Political and Economic Planning, 1959. 28 . 6d.), which emphasizes the stimulus to central economic planning derived in the new countries of Asia from independence and the prospect of foreign aid, gives a clear but concise account of the progress of planning in Pakistan. After reviewing the effects of partition and planning in the early years, the broadsheet outlines the Five Year Plan, published in May 1956 by the Pakistan Planning Board established in July 1953, and then describes the performance and prospects of the plan. Political and Economic Planning concludes that although Pakistan is passing through a difficult phase in its economic, as in its political, development, it is tackling its difficulties with vigour. Performance, however, in some spheres remarkably good, has been uneven, and, regarded as a whole, inadequate. Big mistakes have been made, particularly because of over-ambitious schemes, and too optimistic assumptions about foreign exchange and sterling earnings, and import savings. Brilliant results in industrial development do not balance the failure to develop agriculture. Nevertheless, Pakistan's economy is basically sound. It is learning from past errors and preserving its zeal to plan and work for prosperity.

\section{International Council of Museums}

THE fifth General Conference of the International Council of Museums was held in Stockholm during July 1-8 under the presidency of Dr. Georges Salles (France). The Conference was preceded by meetings of certain committees and commissions held at Oslo and Copenhagen. Dr. Torsten Althin was chairman of the Swedish National Committee which carried out all the complicated organization for the meeting. About 350 delegates attended. The theme of the Conference and the lectures was "Museums as Mirrors - their Potentialities and Limitations". An important session dealt with the inauguration of the International Centre for the study of the preservation and restoration of cultural property. This Centre, established in Rome by the General Conference of Unesco, is designed to strengthen relations between all who are interested in the preservation of their cultural traditions. Dr. H. J. Plenderleith, recently of the British Museum, has been appointed the first director, and at Stockholm he outlined the policy of this new Centre. It aims to collect documentation on the efforts already made in this field, co-ordinate research in order to avoid overlapping, and give advice to all those requesting it. The Centre will also assist and facilitate the training of experts and is destined to become the institution best informed about the results already achieved and the research in progress. The foremost requirement at present is that the great countries should support this venture and ensure its existence after the period guaranteed by Unesco. It was agreed that the next triennial conference should take place in Holland in 1962 under the presidency of Sir Philip Hendy (National Gallery, London).

\section{Geophysical Journal}

THE appearance of the first number of the second volume of the Geophysical Journal, published by the Royal Astronomical Society, is a suitable opportunity to stress the contribution which this journal is making to the growth of pure geophysical research, especially in Great Britain. The fundamental importance of the papers, the careful refereeing and the speedy publication are heartening. Half this particular number contains original material. The other half consists mainly of a review of palæomagnetism and two shorter reports, one on a geophysical meeting and one on current geophysical research in Canada.

\section{The Australian Journal of Statistics}

THF Statistical Society of New South Wales is publishing a new journal, namely, The Australian Journal of Statistics. It is to be issued three times a year, and will contain material relating to statistical theory and methods and their application to all branches of learning. The Journal will give Australian statisticians an opportunity to present their work to the public without undue delay. The editor is H. O. Lancaster. The first number runs to thirtyfour pages, and besides introductory material and a "News and Notes" page, contains three papers. The price of this number is $10 \mathrm{~s}$, which is perhaps a little high for such a slim volume, but even so the Society has had to have outside financial support from some dozen organizations. The Journal will no doubt satisfy a need among Australian statisticians, who are making valuable contributions to the development of statistics, and every success is to be wished to the Society in its new venture. 